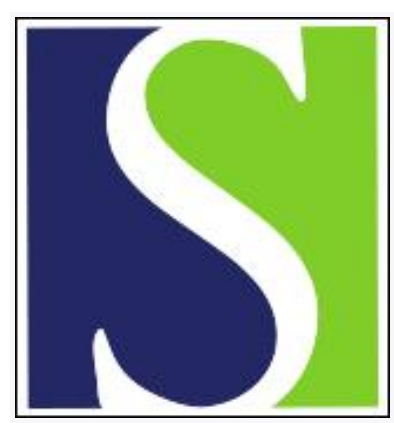

Scand J Work Environ Health 1983;9(4):347-352

https://doi.org/10.5271/sjweh.2402

Issue date: Aug 1983

Platelet function and clotting parameters of vibration-exposed foundry workers.

by Bovenzi M, Fiorito A, Giansante C, Calabrese S, Negro C

This article in PubMed: www.ncbi.nlm.nih.gov/pubmed/6635613

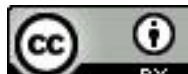




\title{
Platelet function and clotting parameters of vibration-exposed foundry workers
}

\author{
by Massimo Bovenzi, MD, ${ }^{1}$ Antonio Fiorito, MD, ${ }^{1}$ Carlo Giansante, MD, ${ }^{2}$ Salvatore \\ Calabrese, MD, ${ }^{2}$ Corrado Negro, MD1
}

\begin{abstract}
BOVENZI M, FIORITO A, GIANSANTE C, CALABRESE S, NEGRO C. Platelet function and clotting parameters of vibration-exposed foundry workers. Scand $j$ work environ health 9 (1983) 347-352. Platelet aggregation and blood clotting parameters were studied in 22 workers $(84 \%)$ using pneumatic riveting and grinding hand tools and in 20 workers $(90 \%)$ not exposed to vibration but comparable with respect to age, anthropometric data, smoking and drinking habits, and atherogenic risk factors. The weighted acceleration levels of the vibrating tools are reported. According to Taylor's grading system for vibration-induced white fingers, 15 exposed workers $(57 \%)$ were in stage $0_{\mathrm{T}}, 9(34 \%)$ in stage $0_{\mathrm{N}}$, and $1(4 \%)$ in stage 1 . Between the reference and the vibrationexposed groups no differences in the platelet aggregation indices both "in vitro" (adenosine-diphosphate, epinephrine, threshold adenosine-diphosphate concentration) and "in vivo" (platelet factor four, beta-thromboglobulin) were found. In addition the clotting parameters (prothrombin index, activated partial thromboplastin time, fibrinogen, antithrombin III) and the immunoglobulins $G, A$, and $M$ were normal in the two groups. The measurement of skin temperature of the third right finger before and after the cold provocation test showed that the vibration exposed workers experienced a stronger vasoconstriction of the digital vessels than the referents. It is concluded that, in the early stages of vasospastic disorders, segmental vibration can induce peripheral vascular hyperreactivity without changes in the platelet function and clotting parameters.
\end{abstract}

Key terms: cold provocation test, immunoglobulins, peripheral vascular hyperreactivity, Raynaud's phenomenon, skin temperature, weighted acceleration level.

The pathogenic mechanism of the peripheral vasospastic syndrome in workers using handheld vibrating tools is still not fully known. Soviet authors (3) have emphasized the role of an increased vasoconstrictor tone due to the functional sympathetic hyperactivity induced by handarm vibration.

Pyykkö (14) considers that the repeated spasms of the digital arteries provoked by vibration give rise to hypertrophy of the medial vessel wall with a concurrent reduction of blood flow. An appropriate vasomotor stimulation, for instance, exposure to cold, is thus able to trigger acute local ischemia.

1 Institute of Occupational Health, University of Trieste, Italy.

2 Institute of Internal Medicine, University of Trieste, Italy.

Reprint requests to: $\mathrm{Dr} M$ Bovenzi, Istituto di Medicina del Lavoro, Università di Trieste c/o Ospedale Maggiore, Via Stuparich 1, I-34137 Trieste, Italy.
Nerem (10) has noted that the enhancement of shear stress on the arterial wall by segmental vibration of a specific amplitude and frequency can result in endothelial damage; it also affects the arterial wall uptake of proteins and lipids. According to the author, there is a relationship between endothelial damage and Raynaud's phenomenon of occupational origin.

Okada et al (12) have investigated the role of biochemical factors in the pathogenesis of vasospastic disease in two groups of chain-saw workers, one with Raynaud's phenomenon and one without. Haptoglobulin (a component of alpha globulin) and immunoglobulin (Ig) $\mathrm{M}$ were found to be increased in the group with Raynaud's syndrome. The authors believe that an immunologic response might be the cause of the vascular disorders.

It is well known that blood coagulation is altered in patients with secondary Raynaud's phenomenon caused by other clinical conditions, as connective-tissue dis- 
eases (sclerodema, systemic lupus erythematosus, etc). Studies on blood coagulation parameters of users of vibrating tools have given contrasting results.

In vibration workers with Raynaud's phenomenon, Sroczynski et al (15) found increased fibrinogen and a shortened duration of plasma recalcination. On the contrary, hypocoagulability (prolonged Howell time and increased $\mathrm{r}$ and $\mathrm{k}$ time of the thromboelastogram) has been reported for Italian miners examined by Zedda et al (18).

Recently Ikehata et al (5) found a hyperaggregability of platelets and an increase in factor VIII-RA and the von Willebrand factor in 42 patients exposed to chain-saw and rock-drill vibration.

The aim of the present paper was to determine whether early alterations of platelet function and blood coagulation parameters are detectable in workers exposed for a short time to high vibration levels of pneumatic portable tools.

\section{Materials and methods}

\section{Subjects and medical procedures}

Forty-eight men working in the trimming station of a large cast-iron foundry were examined. Twenty-six workers were exposed to hand-arm vibration produced by a riveting hammer (Consolidated Pneumatic Tool C Ltd, $7.3 \mathrm{~kg}, 2000 \mathrm{~b} / \mathrm{min}$ ) and by a horizontal portable grinder (IngersollRand, $5.5 \mathrm{~kg}, 9000 \mathrm{r} / \mathrm{min}$ ). The other 22 workers not exposed to vibration formed the reference group.

Personal health history, work conditions, vibration exposure time, and smoking and alcohol habits were investigated with the use of a questionnaire. To estimate the severity of the neurovascular complaints of the fingers and hands, we have adopted the classification proposed by Taylor et al (16).

A cold provocation test was performed on the exposed and reference groups. The skin temperature was measured by a thermistor at the middle phalanx (dorsal surface) of the third finger of the right hand before immersion in cold water $\left(4^{\circ} \mathrm{C}\right)$ for 2 min. The curve of skin temperature recovery of the right third finger was monitored every $3 \mathrm{~min}$ for $40 \mathrm{~min}$ after the provocation test. The experiments were performed between 1000 and 1200 and the mean room temperature was 22.0 (SD $0.5)^{\circ} \mathrm{C}$.

\section{Laboratory investigations}

Blood samples were obtained from the 48 workers, and the following biochemical parameters were assayed: total and highdensity lipoprotein cholesterol, triglyceride levels, total serum protein, and IgG, IgA and IgM.

In 42 subjects ( 22 exposed and 20 referents) platelet aggregation and coagulation parameters were studied. The blood samples were obtained after an overnight fast, $12 \mathrm{~h}$ of smoking abstinence, and without venous stasis. Platelet aggregation was performed according to Born's photometric method (1). The blood sample was withdrawn into a plastic syringe containing $2.0 \mathrm{ml}$ of $3.8 \%$ sodium citrate $(9 \mathrm{ml}$ of blood to $1 \mathrm{ml}$ of sodium citrate). Plateletrich plasma was prepared by the centrifuging of the citrated blood in plastic tubes at $400 \mathrm{r} / \mathrm{min}$ for $15 \mathrm{~min}$. The supernatant (platelet-rich plasma) was carefully removed and counted in Bürker's chamber with a phase-contrast microscope on a 1: 200 dilution of platelet-rich plasma with platelet diluting fluid (Becton, Dickinson \& Co, monouse pipette system). Platelet aggregation was determined by a photometric method using an ELVI 840 in conjunction with a Logos Omniscribe TM 176 recorder. The aggregometer was set on the assumption that platelet-poor plasma represents $100 \%$ and platelet-rich plasma represents $0 \%$ aggregation. The tube containing that sample $(250 \mu \mathrm{l})$ of plateletrich plasma $\left(300-350,000\right.$ platelets $\left./ \mathrm{mm}^{3}\right)$ was stirred at a constant speed $(1,100$ $\mathrm{r} / \mathrm{min}$ ) and after at least $3 \mathrm{~min} 10 \mu \mathrm{l}$ of an adenosine-diphosphate (ADP) or epinephrine solution was then added to give a final concentration of $0.8,1.2,2.0 \times 10^{-6} \mathrm{M}$ (ADP) and $4.0 \times 10^{-6} \mathrm{M}$ (epinephrine). The results were expressed following Yamazaki's criteria (18).

Beta-thromboglobulin levels were assayed utilizing the Amersham Ria Kit. The blood samples, drawn with the evacuated blood collection tubes (Abbott) (4) containing $2.5 \%$ ethylenediaminetetraacetate, $0.0025 \%$ chloradenosine and $7 \%$ procainehydrochloric acid, were placed in ice water 
for $30 \mathrm{~min}$ before spinning at $2,000 \mathrm{r} / \mathrm{min}$ for $40 \mathrm{~min}$. The top was removed and stored at $-70^{\circ} \mathrm{C}$ until the assay, as described by Ludlam et al (8). Platelet factor four levels were assayed with the use of the Abbott Ria Kit. The collection and the preparation of the samples were the same as previously described for beta-thromboglobulin. Antithrombin III was determined by chromogenic substrate (Abbott Kit) (11). Platelet count, activated partial thromboplastin time (13), one-step prothrombin time (expressed as the prothrombin index), and fibrinogen were also determined.

The measurement of all the parameters expressed as clotting time after recalcification were performed by a semi-automatic instrument which measured the coagulation time (s) of the plasma by the modification of its optical density (Fibrintimer Labor).

The statistical evaluation of the results (Student's t-test, chi-square test) was performed with a personal computer (Apple II).

\section{Vibration measurements}

The one-third octave band frequency spectra of the acceleration levels of the tools used by the foundry workers were measured. The characteristics of the recording and analysis equipment (Brüel \& Kjaer) and the engineering data have been discussed elsewhere (2). In this paper we report the root-mean-square weighted acceleration levels of the tools $\left(a_{w}\right.$ in $\mathrm{m} / \mathrm{s}^{2}$, $8-1,000 \mathrm{~Hz}$ ), computed by the procedure recommended by the International Organization for Standardization (6).

\section{Results}

The exposure time of workers using vibrating tools ranged from 1 to 12 years (mean 5.5 years, SD 3.4 years). The mean estimated work time was $2.4 \mathrm{~h}$ of riveting and $1.1 \mathrm{~h}$ of grinding.

The weighted acceleration sum (X, Y, Z axes) was $42.1 \mathrm{~m} / \mathrm{s}^{2}$ at the handle and $168.1 \mathrm{~m} / \mathrm{s}^{2}$ at the barrel of the riveting hammer, and the weighted acceleration level of the grinder was $8.9 \mathrm{~m} / \mathrm{s}^{2}$.

According to the stage assessment of vibration-induced white fingers developed by Taylor et al (16), the following prevalence of neurovascular complaints of the fingers of the exposed group was found: 1 subject ( $4 \%$ ) had no symptoms (stage 0 ); tingling (stage $0_{\mathrm{T}}$ ) and numbness (stage $0_{\mathrm{N}}$ ) were experienced by $15(57 \%)$ and $9(34 \%)$ workers, respectively; 1 man (4\%) suffered from Raynaud's phenomenon (stage 1). In the reference group only two workers ( $9 \%$ ) were affected with paresthesia in the upper extremities.

In table 1 the characteristics of vibrationexposed workers and the referents are reported. The two groups were comparable with respect to age and anthropometric parameters. The exposed workers smoked more cigarettes and drank more alcohol than the referents, but the differences were not significant. In addition risk factors for atherosclerosis (systolic and diastolic arterial pressure, total and high density lipoprotein cholesterol, triglycerides) were similar in the two groups.

The basal skin temperature values of the third right finger were $32.2(\mathrm{SD} 2.3)^{\circ} \mathrm{C}$ in the exposed workers and 33.5 (SD 1.4$)^{\circ} \mathrm{C}$ in the referents $(p=0.03)$. Fig 1 shows that

Table 1. Characteristics of the vibration-exposed workers and the referents.

\begin{tabular}{|c|c|c|c|c|}
\hline \multirow[t]{2}{*}{ Characteristic } & \multicolumn{2}{|c|}{$\begin{array}{l}\text { Exposed workers } \\
\qquad(N=26)\end{array}$} & \multicolumn{2}{|c|}{$\begin{array}{l}\text { Referents } \\
(N=22)\end{array}$} \\
\hline & Mean & SD & Mean & $\mathrm{SD}$ \\
\hline $\begin{array}{l}\text { Age (years) } \\
\text { Height (cm) } \\
\text { Weight (kg) } \\
\text { Smoking habit (packets of cigarettes) } \\
\text { Alcohol (g/d) } \\
\text { Systolic arterial pressure }\left(\mathrm{mmHg}^{\mathrm{a}}\right) \\
\text { Diastolic arterial pressure }\left(\mathrm{mmHg}^{\mathrm{a}}\right) \\
\text { Total cholesterol (mg/dl) } \\
\text { High-density-lipoprotein cholesterol (mg/dl) } \\
\text { Triglycerides (mg/dl) }\end{array}$ & $\begin{array}{r}36.9 \\
173 \\
79.1 \\
5,470 \\
64.7 \\
125 \\
81.7 \\
211 \\
50.3 \\
113\end{array}$ & $\begin{array}{r}8.1 \\
6.1 \\
8.9 \\
3,175 \\
34.1 \\
11.5 \\
8.7 \\
46.7 \\
8.1 \\
63.1\end{array}$ & $\begin{array}{r}37.9 \\
174 \\
81.1 \\
5,108 \\
52.8 \\
127 \\
81.3 \\
208 \\
57.1 \\
148\end{array}$ & $\begin{array}{r}7.9 \\
6.7 \\
8.9 \\
3,326 \\
21.6 \\
13.3 \\
10.0 \\
44.0 \\
1.8 \\
90.9\end{array}$ \\
\hline
\end{tabular}


Table 2. Platelet aggregation indices and clotting parameters of the vibration-exposed workers and the referents.

\begin{tabular}{|c|c|c|c|c|}
\hline & \multicolumn{2}{|c|}{$\begin{array}{c}\text { Exposed workers } \\
(\mathrm{N}=22)\end{array}$} & \multicolumn{2}{|c|}{$\begin{array}{l}\text { Referents } \\
(\mathrm{N}=20)\end{array}$} \\
\hline & Mean & SD & Mean & SD \\
\hline $\begin{array}{l}\text { As adenosine-diphosphate }(\%) \\
A_{5} \text { epinephrinea }(\%) \\
\text { Adenosine-diphosphate (threshold)b }\left(\times 10^{-6} \mathrm{M}\right) \\
\text { Platelet factor four }(\mathrm{ng} / \mathrm{ml}) \\
\text { Beta-thromboglobulin }(\mathrm{ng} / \mathrm{ml}) \\
\text { Platelet count }\left(\times 10^{3} / \mathrm{mm}^{3}\right) \\
\text { Prothrombin index }(\mathrm{ratio}) \\
\text { Activated partial thromboplastin time (s) } \\
\text { Antithrombin III (\%) } \\
\text { Fibrinogen (mg/dl) }\end{array}$ & $\begin{array}{l}45.8 \\
39.2 \\
0.73 \\
13.6 \\
43.3 \\
249 \\
1.08 \\
28.6 \\
103 \\
242\end{array}$ & $\begin{array}{c}28.6 \\
24.5 \\
0.88 \\
8.4 \\
27.5 \\
53.6 \\
0.07 \\
3.4 \\
18.9 \\
49.0\end{array}$ & $\begin{array}{c}41.9 \\
45.6 \\
0.85 \\
18.6 \\
52.8 \\
234 \\
1.08 \\
29.7 \\
98.1 \\
238\end{array}$ & $\begin{array}{l}27.1 \\
23.8 \\
1.09 \\
8.7 \\
24.4 \\
52.6 \\
0.05 \\
4.4 \\
14.0 \\
80.3\end{array}$ \\
\hline
\end{tabular}

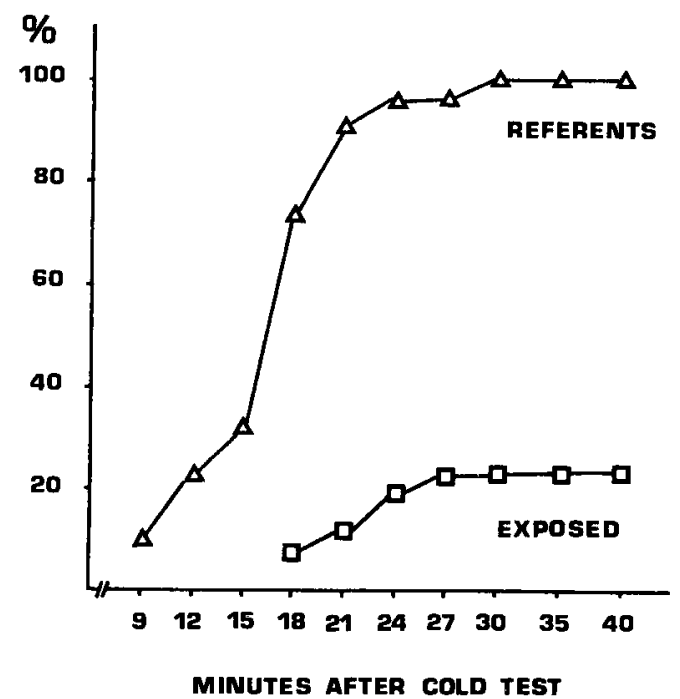

Fig. 1. Cumulative percentage of the reference and vibration-exposed workers recovering the basal skin temperature of the third finger of the right hand $40 \mathrm{~min}$ after the cold provocation test. Statistics (chi-square test): 9 min $p=N S ; 12$ min $p<0.05 ; 15 \min p<0.01 ; 18 \mathrm{~min}-40 \mathrm{~min} p<$ 0.0005 .

there was a marked difference in the cumulative percentage rates of the vibration exposed and reference workers' recovery of the basal skin temperature after the cold provocation test.

In table 2 the mean values and standard deviations of the parameters which explore the platelet and coagulation functions are reported. Platelet count and the indices of platelet aggregation "in vitro" (ADP, epinephrine, threshold ADP concentration) were not significantly different
Table 3. Total serum protein and immunoglobulins (Ig) in the vibration-exposed workers and the referents.

\begin{tabular}{|c|c|c|c|c|}
\hline & \multicolumn{2}{|c|}{$\begin{array}{l}\text { Exposed } \\
\text { workers } \\
(\mathrm{N}=26)\end{array}$} & \multicolumn{2}{|c|}{$\begin{array}{l}\text { Referents } \\
(\mathrm{N}=22)\end{array}$} \\
\hline & Mean & SD & Mean & SD \\
\hline $\begin{array}{l}\text { Total protein } \\
\text { (g/dl) } \\
\text { lgG (mg/dl) } \\
\text { lgA (mg/dl) } \\
\text { lgM (mg/dl) }\end{array}$ & $\begin{array}{r}7.4 \\
1,173 \\
242 \\
136\end{array}$ & $\begin{array}{r}0.5 \\
199 \\
93 \\
66\end{array}$ & $\begin{array}{r}7.5 \\
1,129 \\
226 \\
121\end{array}$ & $\begin{array}{r}0.5 \\
167 \\
108 \\
52\end{array}$ \\
\hline
\end{tabular}

in comparison with those of the referents. Between the two groups no abnormalities were found in the blood levels of platelet factor four and beta-thromboglobulin, which are proteins contained in the platelet alpha granules and secreted during the release reaction.

The values of clotting parameters such as the prothrombin index, activated partial thromboplastin time, fibrinogen, and antithrombin III were similar for the vibration and reference workers.

Total serum protein and the immunoglobulins IgG, IgA, IgM were normal in both groups (table 3 ).

\section{Discussion}

The results of this study suggest that workers exposed to vibration from handheld tools show an intense and longlasting peripheral vasoconstriction after a cold 
provocation test, even if they are not affected with Raynaud's phenomenon. In the vibration group, 20 men ( $76 \%$ ) did not recover their basal skin temperature during the first $40 \mathrm{~min}$ which followed the local cooling, while rewarming of the finger of 20 referents ( $91 \%$ ) occurred within $21 \mathrm{~min}$. This result means that in the vibration-exposed workers the cold stimulation gave rise to a stronger luminal reduction of the digital vessels than in subjects who were not exposed to vibration but were comparable with respect to age, anthropometric data, smoking and drinking habits, and atherogenic factors.

Our laboratory data reveal that the platelet and coagulation functions were not altered in the exposed workers. Between the vibration and reference groups there was no difference in the platelet aggregation indices both "in vitro" (ADP, epinephrine, threshold ADP concentration) and "in vivo" (platelet factor four, betathromboglobulin). The clotting parameters were also normal. The normocoagulability of both groups is well denoted by the antithrombin III level, which is a good index of coagulation "in vivo."

It is difficult to compare these results with those reported by other authors (5, $15,19)$ because they refer to different stages of Raynaud's syndrome. However our findings suggest that, at least in the early stages of vasospastic disease, segmental vibration does not induce endothelial damage, which is one of the most potent activators of platelet aggregation.

According to Knutsson (7) the serum levels of IgG, IgA, and IgM in exposed workers were not significantly raised as compared with referents. This finding contrasts with Okada's immunologic hypothesis for the vasospastic reaction (12).

In conclusion hand-arm vibration, alone or in combination with other stimuli such as cold, noise, and ergonomic conditions, can elicit an abnormal vasoconstrictor response of the digital vessels $(14,17)$. In workers exposed for a short time to high vibration levels, we have found peripheral vascular hyperreactivity that occurs without abnormalities in platelet aggregation and clotting parameters. Other pathogenic factors for the digital ischemia have to be taken into account however, factors such as excessive sympathetic activity (3) or hemodynamic local changes (9).
Nevertheless the results of our study do not exclude the possibility that, in subjects with more severe vibration-induced white fingers (stage 2 or 3 ), hemostatic disorders could play a role in the pathogenesis of Raynaud's phenomenon of occupational origin $(5,15)$.

\section{Acknowledgment}

The authors wish to thank Ms O Fait and Ms L Cornuda for their valuable technical assistance.

\section{References}

1. Born GVR. Aggregation of blood platelets by adenosine diphosphate and its reversal. Nature 194 (1962) 927-929.

2. Bovenzi M, Di Marino F, Morich P, Petronio L. Rischio da vibrazioni segmentali in una fonderia: Aspetti di igiene industriale. Ann ist super sanità 17 (1981) 423-426.

3. Drogitchina EA, Metlina NB. On the classification of the vibration disease [in Russian]. Gig tr prof zabol 11 (1967): 5, 27-31.

4. Eche N, Bonev A, Sie P, Lucot H. Evacuated blood collection tubes and the determination of betathromboglobul in. Thromb res 3 (1981) 323-324.

5. Ikehata $K$, Kawauchi S, Kohno F. Increased platelet function and von Willebrand factor in vibration syndrome. Tokushima j exp med 27 (1980): 2, 23-28.

6. International Organization for Standardization. Draft proposal for a second draft international standard ISO/DIS-5349 "Guide for the measurement and the assessment of human exposure to vibration transmitted to the hand." Deutsches Institut für Normung, Berlin 1982.

7. Knutsson A. Immunoglobulins in workers with traumatic vasospastic disease. J occup med 17 (1975): 11, 706-707.

8. Ludlam CA, Moore $S$, Bolton AE, Pepper DS, Cash JD. The release of a human platelet specific protein measured by RIA. Thromb res 6 (1975) 543-548.

9. Mellander S, Johansson B. Control of resistance, exchange and capacitance functions in the peripheral circulation. Pharmacol rev 20 (1968): 3, 117-196.

10. Nerem RM. Vibration-induced arterial shear stress: The relationship to Raynaud's phenomenon of occupational origin. Arch environ health 26 (1973) 105-110.

11. Odegard OR, Lie M, Abilgaard U. Heparin cofactor activity measured with amidolytic method. Thromb res 6 (1975) 287-294.

12. Okada A, Yamashita T, Nagaro C, Ikeda T, Yachi A, Shibata S. Studies on the diagnosis and pathogenesis of Raynaud's phenomenon of occupational origin. $\mathrm{Br} \mathrm{j}$ ind med 28 (1971) 353-357.

13. Proctor RR, RapaportSI. The partial throm- 
boplastin time with kaolin. Am j clin pathol 1 (1961) 36-40.

14. Pyykkö I. A physiological study of the vasoconstrictor reflex in traumatic vasospastic disease. Work environ health 11 (1974) 170-186.

15. Sroczynski J, Wegiel A, Pigon W. Blood coagulation system in workers exposed to noise and vibration. Med proc 30 (1979): 1, 41-47.

16. Taylor W, Pelmear PL, Pearson J. Raynaud's phenomenon in forestry chain saw operators. In: Taylor W, ed. The vibration syndrome. Academic Press, London 1974, pp 121-139.
17. Teisinger J, Louda L. Vascular disease disorders resulting from vibrating tools. J occup med 14 (1972): 2, 129-133.

18. Yamazaki H, Takahashi T, Sano T. Hyperaggregability of platelets in thromboembolic disorders. Thromb diath haemorrah 34 (1975) 94-105.

19. Zedda S, Marracini L, Sergiacomi R. Sul comportamento dell'emocoagulazione negli operai addetti all'uso di strumenti vibranti. Rass med sarda 71 (1968): 6, 608-618.

Received for publication: 21 March 1983 